\title{
Overt Dangerous Behavior as a Constitutional Requirement for Involuntary Civil Commitment of the Mentally Ill
}

Eight states have recently enacted mental health statutes that limit involuntary civil commitment to persons who are dangerous to others or themselves and require a showing that dangerousness has been manifested in recent conduct.' During the same period several state and federal courts have held that this overt dangerous behavior ${ }^{2}$ standard is mandated by the Constitution, ${ }^{3}$ but some

11975 Ala. Acts 2562,2566 (Act No. 1226, $§ 10$ ); CAL. WeLF. \& INST'NS CoDE $\$ \S 5260$, 5300 (West 1972); 1976 Hawaii Sess. Laws Act 130, $\S 1$; Mass. Gen. Laws AnN. ch. 123, $\S 1$ (1972); Neb. Rev. Stat. § 83-1009 (1976); N.C. Gen. Stat. § 122-58.3 (1974) (repealed 1974); WaSh. Rev. Code ANN. $\S 71.05020$ (1975); 1975 Wis. Laws ch. 430, $\S 51.15, .20$. Alabama, Nebraska, and Wisconsin each enacted a dangerous behavior requirement in response to a case invalidating a prior statute that lacked such a requirement. See Doremus v. Farrell, 407 F. Supp. 509 (D. Neb. 1975); Lynch v. Baxley, 386 F. Supp. 378 (M.D. Ala. 1974); Lessard v. Schmidt, 349 F. Supp. 1078 (E.D. Wis. 1972), vacated and remanded for a more specific order, 414 U.S. 473, order on remand, 379 F. Supp. 1376 (1974), vacated and remanded on other grounds, 421 U.S. 957 (1975), order reinstated on remand, 413 F. Supp. 1318 (1976).

2 The courts that have considered an overt dangerous behavior requirement have often used the language of "overt act." See, e.g., Stamus v. Leonhardt, 414 F. Supp. 439 (S.D. Iowa 1976); Doremus v. Farrell, 407 F. Supp. 509 (D. Neb. 1975); United States ex rel. Mathew v. Nelson, No. 72-C-2104 (N.D. Ill. Aug. 18, 1975), noted in 7 Loy. Crr. L.J. 507 (1976); Lynch v. Baxley, 386 F. Supp. 378 (M.D. Ala. 1974); Lessard v. Schmidt, 349 F. Supp. 1078 (E.D. Wis. 1972), vacated and remanded for a more specific order, 414 U.S. 473 (1974), order on remand, 379 F. Supp. 1376 (1974), vacated and remanded on other grounds, 421 U.S. 957 (1975), order reinstated on remand, 413 F. Supp. 1318 (1976); Commonwealth ex rel. Finken v. Roop, 234 Pa. Super. 155, 339 A.2d 764 (1975), appeal dismissed, 424 U.S. 960 (1974). In a later order Lessard modified its language to "recent act, attempt or threat." 379 F. Supp. at 1379.

Unfortunately, "overt act" is also a term of art in the criminal law, where it is construed quite broadly. Very little is required for an "overt act" in a conspiracy prosecution, and the act itself may be completely innocuous. See Yates v. United States, 354 U.S. 298 (1957). See generally W. LAFAve \& A. ScotT, HANDBOOK ON CRIMINAL LAw 476-78 (1972). In addition, the term "overt act" is confusing because the relevant behavior for civil commitment includes inchoate conduct such as an attempt or a threat and may also include ornissions.

Despite these defects, the case law has adopted the terminology of "overt act," and this label promises to become a term of art in civil commitment law. This comment employs the terminology of "overt dangerous behavior" in an effort to avoid the ambiguities and confusing connotations of "overt act."

${ }^{3}$ See, e.g., Stamus v. Leonhardt, 414 F. Supp. 439 (S.D. Iowa 1976); Doremus v. Farrell, 407 F. Supp. 509 (D. Neb. 1975); Lynch v. Baxley, 386 F. Supp. 378 (M.D. Ala. 1974); Bell v. Wayne County Gen. Hosp., 384 F. Supp. 1085 (E.D. Mich. 1974); Lessard v. Schmidt, 349 F. Supp. 1078 (E.D. Wis. 1972), vacated and remanded for a more specific order, 414 U.S. 473, order on remand, 379 F. Supp. 1376 (1974), vacated and remanded on other grounds, 421 U.S. 957 (1975), order reinstated on remand, 413 F. Supp. 1318 (1976); Dixon v. Attorney Gen., 325 F. Supp. 966 (M.D. Pa. 1971) (semble); Commonwealth ex rel. Finken v. Roop, 
other courts have expressly rejected such a requirement. ${ }^{4}$ In 1975 the Supreme Court considered the constitutionality of the standards for involuntary civil commitment in $O^{\prime}$ Connor $v$. Donaldson. 'The Court left most questions unanswered, however, by its narrow holding that the Constitution does not allow a state to confine a person in a mental institution against his will if the person is neither dangerous, nor incapable of surviving safely alone or with friends, nor in need of treatment that requires confinement. The lower courts that have adopted an overt dangerous behavior requirement have moved beyond Donaldson by declaring that the Constitution requires a finding of "dangerousness" as a prerequisite to any involuntary confinement of the mentally ill-whether or not treatment is provided-and by requiring that such a finding be supported by a tangible item of proof.

This comment considers whether the lower courts have been justified in making overt dangerous behavior a constitutional prerequisite to involuntary civil commitment. After discussing Donaldson's potential impact on the permissible grounds for civil commitment, the comment reviews the cases that have either adopted or refused to adopt an overt dangerous behavior requirement, examines the definitions of "dangerousness" and "overt dangerous behavior," and analyzes the arguments advanced in the cases favoring the constitutionalization of an overt dangerous behavior requirement.

\section{O'Connor v. Donaldson: The Supreme Court and the Permissible Grounds for Civil Commitment}

The standards and procedures governing involuntary civil commitment in many states seem inconsistent with the concerns for due process that qualify the criminal justice system. The stigma and loss of liberty imposed on those who are committed are often barely distinguishable from the analogous burdens imposed on criminals and may be even more severe. ${ }^{6}$ Yet many of the substantive and procedural protections available to alleged criminals have been denied to persons alleged to be mentally ill. The lack of procedural due

$234 \mathrm{~Pa}$. Super. 155, 339 A.2d 764, 776-79 (1975) (only three of seven judges agreed on this point), appeal dismissed, 424 U.S. 960 (1976).

- United States ex rel. Mathew v. Nelson, No. 72-C-2104 (N.D. Ill. Aug. 18, 1975), noted in 7 Loy. CH. L.J. 507 (1976); People v. Sansone, 18 Ill. App. 3d 315, 309 N.E.2d 733 (1974); In re Salem, 31 N.C. App. 57, 228 S.E.2d 649 (1976).

s 422 U.S. 563 (1975).

- See, e.g., Developments in the Law-Civil Commitment of the Mentally Ill, 87 Harv. L. Rev. 1190, 1193-201 (1974) [hereinafter cited as Developments-Civil Commitment]. 
process in civil commitment has received increasing attention from courts and commentators. ${ }^{7}$ Similarly, the phenomenon this comment examines-the recent interest of both legislatures and lower courts in an overt dangerous behavior requirement-indicates a growing concern that the standards for civil commitment do not satisfy the mandates of substantive due process.

Unlike the criminal law, which is based on a retributiondeterrence approach, ${ }^{8}$ the law of civil commitment is built around a prediction-prevention model..$^{9} \mathrm{~A}$ person may be sent to prison for a criminal offense only after being convicted of having committed the particular offense, and the term of imprisonment is fixed in relationship to the offense..$^{10}$ On the other hand, in many states a person may be committed against his will to a mental institution for an indeterminate period on a psychiatrist's testimony that he is "mentally ill" and a prediction that if he remains free he will be "dangerous" to himself or others, or a certification that he is in need of care, custody, or treatment."

These substantive differences between civil commitment and the criminal justice system are frequently explained by pointing out the distinctive purposes of civil commitment. States have traditionally based their authority to commit the mentally ill on two sources: the parens patriae power, which can be traced back to the sovereign's responsibility to protect the properties of a subject who was incompetent to handle his own affairs, ${ }^{12}$ and the police power, by which the state seeks to protect other citizens from a person whose mental condition renders him "dangerous." 13 These traditional pow-

'See, e.g., Lessard v. Schmidt, 349 F. Supp. 1078, 1090-93, 1097-103 (E.D. Wis. 1972), vacated and remanded for more specific order, 414 U.S. 473 (1974), on remand, 379 F. Supp. 1376 (E.D. Wis. 1974), vacated and remanded on other grounds, 421 U.S. 957 (1975), order reinstated on remand, 413 F. Supp. 1318 (E.D. Wis. 1976); Developments-Civil Commitment, supra note 6 , at $1265-1316$.

${ }^{x}$ The criminal justice system contains elements of the prediction-prevention approach as well as the retribution-deterrence approach, but the basic thrust of the system is clearly the latter. See generally Dershowitz, The Law of Dangerousness: Some Fictions About Predictions, 23 J. LEGal ED. 24, 27-32 (1970).

Dershowitz, supra note 8, at 32-47.

10 There are exceptions to this generalization, the most important of which are the practices classified as "preventive detention." See Dershowitz, supra note 8, at 29-32; Foote, Comments on Preventive Detention, 23 J. Legal Ed. 48 (1970).

" See American Bar Foundation, The Mentally Disabled and the Law 36-41, 66-71, 91 95 (rev. ed. S. Brakel \& R. Rock 1971); Developments-Civil Commitment, supra note 6, at 1201-07.

${ }^{12}$ See generally Dershowitz, supra note 8, at 33-35; Ross, Commitment of the Mentally Ill: Problems of Law and Policy, 57 Mrch. L. Rev. 945, 956-60 (1959); Developments-Civil Commitment, supra note 6, at 1207-22.

13 See generally Ross, supra note 12, at 955-56; Developments-Civil Commitment, supra note 6 , at $1222-45$. 
ers provide the foundations for the most common current justifications for involuntary civil commitment: protecting other persons from being harmed by a person whose condition makes him unable to respond to the normal social and legal sanctions against violent behavior, preventing the mentally ill person from harming himself, providing a minimum of care and custody for those unable to survive safely in freedom, and providing treatment for those unable to make responsible treatment decisions for themselves. ${ }^{14}$

The criminal justice approach, based on deterring antisocial actions by establishing punitive sanctions designed to affect the conscious decisions of responsible individuals, is said to be inappropriate in a context where individuals are regarded as incapable of responding to "normal" incentives and thus not responsible for their actions..$^{15}$ Furthermore, when the state is acting in a beneficent capacity (under the parens patriae power), rather than a punitive one, substantive and procedural protections are supposedly less necessary. ${ }^{16}$ Moreover, a prediction-prevention approach, focusing on and limited by the treatment of a disease rather than retribution or

1s Statutes, courts, and commentators have formulated these aims differently and have at times combined or confused them. See, e.g., Jackson v. Indiana, 406 U.S. 715, 737 (1972); Donaldson v. O'Connor, 493 F.2d 507, 520-21 (5th Cir. 1974), remanded, 422 U.S. 563 (1975); american Bar Foundation, The Mentally Disabled and the Law 38 (rev. ed. S. Brakel \& R. Rock 1971); Livermore, Malmquist \& Meehl, On the Justifications for Civil Commitment, 117 U. PA. L. REv. 75 (1968); Note, Civil Commitment of the Mentally Ill: Theories and Procedures, 79 HaRv. L. REv. 1288, 1289-97 (1966); Note, The Nascent Right to Treatment, 53 VA. L. REv. 1134, 1138-39 (1967). Prevention of dangerousness to self is a hybrid goal that is outside the strict formulation of either the police power or the parens patriae power, but partakes of elements of both. See Donaldson v. O'Connor, 493 F.2d 507, 521 (5th Cir. 1974), remanded, 422 U.S. 563 (1975); Note, Civil Commitment of the Mentally Ill, supra, 1293-95.

Courts and commentators have also mentioned some other explanations for civil commitment that lack the legitimacy of the more widely recognized goals. These include the desire to protect others from the embarrassment of being exposed to mentally ill persons, the desire to assure that the mentally ill maintain a minimum living standard, and the inability of those who are classified as mentally ill to defend themselves effectively against assaults on their liberty. See generally Livermore, Malmquist \& Meehl, supra; Slovenko, Civil Commitment in Perspective, 20 J. PuB. L. 3 (1971). The Supreme Court in O'Connor v. Donaldson, 422 U.S. 563 (1975), in effect rejected all but the traditionally recognized justifications for involuntary commitment. See text and notes at notes 21-34 infra.

15 This rationale is logically limited to commitments of persons whose mental condition would qualify them for an insanity defense in a criminal prosecution for the acts they are predicted to commit. See Livermore, Malmquist \& Meehl, supra note 14, at 86.

1" The most significant example of this rationalization is the "quid pro quo" theory used by some to justify a "right to treatment." According to this argument, lower procedural and substantive protections are counterbalanced by the "benefit" conferred by a right to receive treatment. See, e.g., Donaldson v. O'Connor, 493 F.2d 507, 521-22 (5th Cir. 1974), remanded, 422 U.S. 563 (1975). The quid pro quo theory has been criticized as a dangerous concept that might undercut valuable due process protections by justifying one deprivation of liberty (commitment) by a further deprivation of liberty (compulsory treatment). See, e.g., O'Connor v. Donaldson, 422 U.S. 563, 585-87, 589 (Burger, C.J., concurring). 
deterrence, resembles the approach doctors normally follow in dealing with nonmental illnesses.

Despite these historical and theoretical distinctions, the obvious similarities between the practical effects of civil commitment and of criminal conviction have led some commentators to question the differences between the substantive standards that apply in the two situations. ${ }^{17}$ The police power rationale authorizes commitments that are no more "beneficent" than sentences given to convicted criminals, and medical science's limited understanding of mental illnesses weakens the appeal of a theory of compulsory "treatment." 18 Some commentators have even asserted that civil commitment has provided society with an insidious method of evading the constitutional requirements of due process while depriving a powerless minority of their liberty. ${ }^{19}$

The Supreme Court has dealt indirectly with similar questions about the standards for civil commitment in several cases involving the commitment of persons accused of criminal activity, ${ }^{20}$ but the

17 See Dershowitz, supra note 8, at 32-47; Foote, supra note 10.

is In spite of medical science's relative ignorance about mental illness, compulsory treatment of the mentally ill is supposedly justified because mentally ill persons are incapable of making a rational choice whether to undergo treatment. This rationale can become circular if a refusal to undergo treatment is considered as evidence of irrationality. See Livermore, Malmquist \& Meehl, supra note 14, at 88 n.36; Developments-Civil Commitment, supra note 6 , at $1212-19$.

13 See, e.g., Foote, supra note 10; Frankel, Comments on Preventive Detention, $23 \mathrm{~J}$. LEGAL ED. 53 (1970).

${ }^{20}$ See McNeil v. Director, Patuxent Institution, 407 U.S. 245 (1972); Jackson v. Indiana, 406 U.S. 715 (1972); Humphrey v. Cady, 405 U.S. 504 (1972); Baxstrom v. Herold, 383 U.S. 107 (1966); Greenwood v. United States, 350 U.S. 366 (1956). The Supreme Court has generally proceeded cautiously when considering the standards for involuntary civil commitment. In Greenwood the Court upheld the authority of the United States under 18 U.S.C. $\$ \S 4244$ 4248 (1970) to commit a person indicted for a federal crime who was found to be incompetent to stand trial and likely to "endanger the officers, property, or other interests of the United States" if released. 350 U.S. at 375 . Justice Frankfurter, writing for a unanimous Court, limited his holding to sustaining only the initial commitment of the prisoner, and expressly denied deciding more than the specific situation presented or implying "an opinion on situations not now before us." Id. at 376. Greenwood is the only case in which the Court has squarely upheld a government's authority to commit a mentally ill or defective person against his will.

In the cases following Greenwood the Court has invalidated what amounted to commitments of persons charged with or convicted of crimes when these persons had been denied the substantive or procedural protections afforded under state statutory provisions governing civil commitment. These cases have usually relied on the equal protection clause, though at least one case also reached the due process issue. See Jackson v. Indiana, 406 U.S. 715, 73139 (1972). Some of these cases contain dicta interpreting state statutes to require a finding of dangerousness and suggesting that this interpretation is mandated by constitutional concerns. See id. at 728, 737; Humphrey v. Cady, 405 U.S. 504, 509 (1972) (Wisconsin statute "conditions such confinement not solely on the medical judgment that the defendant is 
Court did not directly address the standards for involuntary civil commitment outside the criminal context until its 1975 opinion in O'Connor $v$. Donaldson. ${ }^{21}$ Kenneth Donaldson was involuntarily confined in a mental institution for nearly fifteen years although he posed no danger to others and was not thought likely to inflict injury on himself. ${ }^{22} \mathrm{Had}$ he been permitted to live outside the institution, responsible friends were willing to provide any care he might have needed. ${ }^{23}$ During his confinement he received only custodial care and no treatment. ${ }^{24}$ After several unsuccessful attempts to secure his release ${ }^{25}$ Donaldson brought a suit seeking his freedom and damages against those responsible for his continued confinement. A jury found that Donaldson's constitutional right to liberty had been violated and awarded him compensatory and punitive damages. The court of appeals affirmed, holding that under the circumstances Donaldson had been deprived of a constitutional right to treatment and stating that whenever a mentally ill person is civilly committed against his will he has "a constitutional right to receive such treatment as will give him a reasonable opportunity to be cured or to improve his mental condition." 26

The Supreme Court agreed that Donaldson's confinement was unconstitutional, but found that the right-to-treatment issue was "not presented by this case in its present posture"27 and took pains to frame its holding very narrowly. Following a barely articulated due process interest-balancing approach, the Court held that none of the state interests involved in Donaldson's case had justified the deprivation of his liberty by continued confinement. After declaring

mentally ill and treatable, but also on the social and legal judgment that his potential for doing harm, to himself or to others, is great enough to justify such a massive curtailment of liberty").

21422 U.S. 563 (1975), noted in Note, "Without More": A Constitutional Right to Treatment, 22 LoY. L. REv. 373 (1976); Note, Supreme Court Sidesteps the Right to Treatment Question, 47 U. Colo. L. Rev. 299 (1976); 9 AKRoN L. Rev. 374 (1975); 13 CAL. West. L. Rev. 168 (1976); 24 Clev. St. L. Rev. 557 (1975); 7 Colum. Human Rights L. Rev. 573 (1975); 3 Hast. Const. L.Q. 599 (1976); 4 Horstra L. Rev. 511 (1976); 53 J. URBan L. 305 (1975); 37 Mont. L. Rev. 227 (1976); 7 N.C. CENT. L.J. 174 (1975); 3 Oho N.U.L. Rev. 550 (1975); 29 OkLA. L. Rev. 117 (1976); 10 Sufrolk U.L. Rev. 76 (1975); 43 TeNN. L. Rev. 366 (1976); 50 Tulane L. Rev. 699 (1976); 10 U. Rich. L. Rev. 402 (1976); 51 WaSh. L. Rev. 733 (1976).

2422 U.S. at 568.

2 Id. at 568-69.

24 Id. at 569. During his confinement Donaldson may have at times refused certain types of treatment on religious grounds. Id. at 569 n.4; Donaldson v. O'Connor, 493 F.2d 507, 511 (5th Cir. 1974).

${ }^{25}$ See, e.g., Donaldson v. O'Connor, 493 F.2d 507, 515-17 (5th Cir. 1974).

24 Id. at 527 .

27422 U.S. at 573. 
that a mere finding of mental illness provides no constitutional basis for confinement, the Court proceeded to dismiss two other possible justifications for Donaldson's confinement. The state's interest in ensuring that the mentally ill are provided with care and assistance to maintain a certain minimum living standard was insufficient because "the mere presence of mental illness does not disqualify a person from preferring his home to the comforts of an institution." 28 The state's interest in protecting other citizens from exposure to the mentally ill was also too weak: "public intolerance or animosity cannot constitutionally justify the deprivation of a person's physical liberty." 29

Finding that the state interests actually present in Donaldson's case did not justify his confinement, the Court expressly disclaimed deciding

whether, when, or by what procedures, a mentally ill person may be confined by the State on any of the grounds which, under contemporary statutes, are generally advanced to justify involuntary confinement of such a person-to prevent injury to the public, to ensure his own survival or safety, or to alleviate or cure his illness. ${ }^{30}$

None of these "generally advanced" grounds was available to justify Donaldson's confinement. His confinement could not be sustained as preventing injury to the public because he was not dangerous. Nor could it be sustained as ensuring his own safety because he was not suicidal or likely to inflict injury on himself and would be able to live safely in freedom. Finally, his confinement could not be justified as alleviating or curing his illness because no treatment had been provided.

Construed narrowly, Donaldson is an unsurprising holding: involuntary confinement of the mentally ill is impermissible when none of the generally accepted grounds is present. The opinion indicates that at least a finding of dangerousness or incapacity to survive in freedom is necessary when no treatment is provided, but the Court did not define "dangerousness" with any specificity or decide whether a finding of dangerousness is always necessary-or sufficient $^{31}$-for commitment. The Court also sidestepped the difficult

${ }^{2 *}$ Id. at 575 .

${ }^{29}$ Id.

${ }^{30} \mathrm{Id}$. at $573-74$.

31 On the sufficiency of dangerousness as a ground for civil commitment, see Greenwood v. United States, 350 U.S. 366 (1956), discussed in note 20 supra, where the Court upheld a commitment based in part on a finding of dangerousness to the "officers, property, or other 
issues of what evidence is required to establish dangerousness (e.g., whether overt dangerous behavior must be proved) and what can count as "treatment." The defendants did not contradict the testimony that Donaldson was not dangerous, ${ }^{32}$ and the Court relied on the jury's verdict "based on abundant evidence" that Donaldson had received no treatment. ${ }^{33}$

The Donaldson opinion thus leaves the Supreme Court with maximum flexibility, and the lower courts with minimal directions, on these issues in future cases. Nevertheless, the opinion does provide a guide to how purported justifications for involuntary civil commitment should be evaluated-by employing due process interest balancing supplemented with a least restrictive means test ${ }^{34}$ - and perhaps implies that the three "generally advanced" justifications will weigh more heavily in the balance against the individual's liberty interest than did the state interests present in Donaldson.

\section{Lower Court Cases Dealing with an Overt Dangerous BeHAVIOR REQUIREMENT}

The lower courts both before and after Donaldson have shown less restraint in addressing whether the Constitution requires that a person be found "dangerous" before he can be subjected to involuntary civil commitment, and, if so, whether the evidence of such "dangerousness" must include proof of overt dangerous behavior. The decisions considering these issues have reached mixed results, and the depth of their analyses is limited, but they do articulate the major arguments for and against an overt dangerous behavior requirement.

The leading case adopting an overt dangerous behavior requirement is Lessard $v$. Schmidt, ${ }^{35}$ a 1972 decision in which a three-judge

interests of the United States." Later cases have followed the Court's suggestion in Greenwood that the holding of the case be limited to its particular facts. See Jackson v. Indiana, 406 U.S. 715, 731-33, 737 (1972).

32422 U.S. at 568 .

ss Id. at 573.

34 The Court indicated its concern that the least restrictive means be used when it discussed the state's interest in ensuring a minimum living standard for the mentally ill: "[W]hile the State may arguably confine a person to save him from harm, incarceration is rarely if ever a necessary condition for raising the living standards of those capable of surviving safely in freedom, on their own or with the help of family or friends. See Shelton v. Tucker, 364 U.S. 479, 488-490 [(1960)]."

${ }^{35} 349$ F. Supp. 1078 (E.D. Wis. 1972), vacated and remanded for a more specific order, 414 U.S. 743, order on remand, 379 F. Supp. 1376 (1974), vacated and remanded on other grounds, 421 U.S. 957 (1975), order reinstated on remand, 413 F. Supp. 1318 (1976). 
federal district court considered allegations that the Wisconsin civil commitment statute ignored less drastic alternatives and was vague and overbroad. The court was able to construe the statute so that it was not impermissibly vague or overbroad by reading in an implicit requirement that the person to be committed be found "dangerous." 36 The court balanced the individual's interest against the state's and concluded that involuntary commitment is constitutionally justified only if there is an "extreme likelihood that if the person is not confined he will do immediate harm to himself or others." ${ }_{37}$ The court then commented on how this "extreme likelihood" might be proved:

Although attempts to predict future conduct are always diffi-
cult, and confinement based upon such a prediction must al-
ways be viewed with suspicion, we believe civil confinement
can be justified in some cases if the proper burden of proof is
satisified and dangerousness is based upon a finding of a recent
overt act, attempt or threat to do substantial harm to oneself
or another. ${ }^{38}$

The court evidently regarded overt dangerous behavior as necessary to establish a sufficiently high probability of harm. ${ }^{39}$ Lessard's holding has been put in some doubt, as the Supreme Court has twice vacated the case on other grounds. ${ }^{40}$ The court has since reinstated its order ${ }^{41}$ and the issue is now moot because Wisconsin has enacted a new statute that requires overt dangerous behavior. ${ }^{42}$

36 Id. at 1093 .

37 Id.

${ }^{38}$ Id. (citing Cross v. Harris, 418 F.2d 1095, 1102 (D.C. Cir. 1969) (requiring a "high probability of serious harm" for commitment under a sexually dangerous offenders statute)).

39 The court supported its requirement of proof of dangerousness by comparing mentally ill persons to physically ill persons, who are allowed to choose whether to undergo treatment. The court conceded that a difference might be justified where a state could prove "that the person is unable to make a decision about hospitalization because of the nature of his illness." Id. at 1094. Nevertheless, pointing out the generally recognized ambiguity of any definition of "mental illness," the court asserted that

it is not difficult to see that the rational choice in many instances would be to forego treatment, particularly if it carries with it the stigma of incarceration in a mental institution, with the difficulties of obtaining release, the curtailments of many rights, the interruption of job and family life, and the difficulties of attempting to obtain a job, drivers license, etc. upon release from the hospital.

Id. The court also held that "the state must prove beyond a reasonable doubt all facts necessary to show that an individual is mentally ill and dangerous," id. at 1095, and must demonstrate that confinement is the least restrictive alternative. Id. at 1095-96.

so 414 U.S. 743 (1974); 421 U.S. 957 (1975).

4413 F. Supp. 1318 (E.D. Wis. 1976).

${ }^{2} 1975$ WIS. LAws ch. $430, \S \S 51.15(1), 51.20(1)$ (a) (text of statute may be found at note 77 infra). 
In the earlier case of Dixon $v$. Attorney General ${ }^{43}$ a three-judge court found Pennsylvania's mental health statute to be "almost completely devoid of the due process of law required by the Fourteenth Amendment." 4 The consent decree included a standard for commitment: "[T]he evidence found to be reliable by the factfinder must establish clearly, unequivocally and convincingly that the subject of the hearing requires commitment because of manifest indications that the subject poses a present threat of serious physical harm to other persons or to himself." 45 Although "manifest indications" could be interpreted to require only behavior that supports a diagnosis that an individual is in a category of persons who will probably harm others or himself, the court probably intended a standard similar to that in Lessard. ${ }^{46}$

Bell v. Wayne County General Hospital ${ }^{47}$ involved a vagueness attack on Michigan's statute. The court held that without a showing of dangerousness the statute was impermissibly vague and noted that in order "to validate the 'massive curtailment of liberty' which involuntary commitment occasions, the basis for confinement must be in threatened or actual behavior stemming from the mental disorder, and of a nature which the state may legitimately control, viz., that causing harm to self or others." 48 The court's language is ambiguous, as "threatened" behavior could be read to include any prediction of dangerous behavior. The court's order was limited to requiring dangerousness and did not mention an overt dangerous behavior requirement to implement the dangerousness standard. ${ }^{+9}$

Lynch v. Baxley ${ }^{50}$ involved a challenge to Alabama's mental health statute. The federal court mandated minimum due process safeguards and held that involuntary commitment must be based on dangerousness. ${ }^{51}$ Relying on Lessard, the court went on to require overt dangerous behavior. The court characterized the issue as one regarding the sufficiency of the evidence and then reasoned:

A mere expectancy that danger-productive behavior might be engaged in does not rise to the level of legal significance when

325 F. Supp. 966 (M.D. Pa. 1971).

"Id. at 972.

15 Id. at 974.

* See Developments-Civil Commitment, supra note 6, at 1206.

17384 F. Supp. 1085 (E.D. Mich. 1974).

* Id. at 1096 (emphasis added) (quoting Humphrey v. Cady, 405 U.S. 504, 509 (1972)).

" 384 F. Supp. at 1102. The plaintiffs had also argued that commitment under the current statute was an unconstitutional punishment for status. Id. at 1095.

so 386 F. Supp. 378 (M.D. Ala. 1974).

31 Id. at $389-91$. 
the consequence of such an evaluation is involuntary confinement. To confine a citizen against his will because he is likely to be dangerous in the future, it must be shown that he has actually been dangerous in the recent past and that such danger was manifested by an overt act, attempt or threat to do substantial harm to himself or to another. ${ }^{52}$

In Commonwealth ex rel. Finken v. Roop ${ }^{53}$ the Pennsylvania Superior Court declared a provision of Pennsylvania's mental health statute unconstitutionally vague and held that both dangerousness and evidence of overt dangerous behavior were required for commitment:

In light of the difficulty of predicting that a given mental state is likely to result in future antisocial conduct, it seems necessary to require the commission of some overt act. When coupled with psychiatric evaluation, the court will then be in a better position to assess the likelihood of the individual committing similar acts. The court should not order commitment unless it is convinced that the probability of such acts occurring is substantial. ${ }^{54}$

Nebraska's involuntary commitment statute was found unconstitutionally vague and overbroad in Doremus $v$. Farrell..$^{55}$ The court reasoned that dangerousness is required because the state must have a compelling interest in confinement, ${ }^{56}$ and implemented the dangerousness standard with an overt dangerous behavior requirement:

Due process and equal protection require that the standards for commitment must be (a) that the person is mentally ill and poses a serious threat of substantial harm to himself or to others; and (b) that this threat of harm has been evidenced by a recent overt act or threat. The threat of harm to oneself may be through neglect or inability to care for oneself..$^{57}$

In Stamus v. Leonhard $t^{58}$ a federal district court relied on

${ }^{32}$ Id. at 391.

${ }_{53} 234$ Pa. Super. 155, 339 A.2d 764 (1975), appeal dismissed, 424 U.S. 960 (1976). Finken involved a challenge to a different provision of the mental health statute from Dixon $v$. Attorney Gen., 229 F. Supp. 966 (M.D. Pa. 1971), where a federal court found the relevant provision of Pennsylvania's statute unconstitutional.

st $234 \mathrm{~Pa}$. Super. 155, 183-84, 339 A.2d at 778-79.

35407 F. Supp. 509 (D. Neb. 1975).

se Id. at 514.

57 Id. at 514-15.

${ }^{58} 414$ F. Supp. 439 (S.D. Iowa 1976). 
Doremus to hold Iowa's involuntary commitment statute impermissibly vague. The court quoted Doremus at length and then announced, "This court therefore holds that the commitment standards . . . violated substantive due process by not requiring that subjects pose a serious threat to themselves or others, as evidenced by a recent overt act, attempt or threat." ${ }^{50}$ However, in a numbered statement of conclusions the court failed to mention an overt dangerous behavior requirement. ${ }^{60}$

Thus, several cases have espoused an overt behavior requirement, and these cases have suggested several different rationales. But for the most part the courts have failed to either articulate clearly or analyze fully the rationale for the requirement. The principal holding of each case is that involuntary commitment is justified only when an individual is dangerous. The courts have then required that overt behavior evidence the individual's dangerousness. The courts have in other words made dangerousness the standard for commitment and then required overt behavior as a means of proving dangerousness.

Several courts have refused to adopt an overt dangerous behavior requirement. In People $v$. Sansone the Illinois appellate court considered a contention that "in the absence of proof of prior dangerous behavior, civil commitment is preventive detention, and violative of due process." 61 The court distinguished criminal punishment from detention based on a law that requires treatment and held that commitment was not punishment for status. ${ }^{62}$ The due process argument was also rejected: "Due process does not require that a person be charged with a specific dangerous overt act, but that there be a nexus between the facts asserted and a finding of "in need of treatment." "63

In United States ex rel. Matthew $v$. Nelson ${ }^{64}$ a three-judge federal district court considered another attack on the Illinois commitment statute. Because the Illinois statute requires dangerousness, the court faced only the question whether overt dangerous behavior was constitutionally necessary. The court was presented with conflicting expert testimony regarding the reliability of predictions of dangerousness in the absence of overt behavior. In light of this testi-

\footnotetext{
3s Id. at 451 .

so Id. at 453 .

a 18 Ill. App. 3d 315, 317, 309 N.E.2d 733, 735 (1974).

2 Id. at 324,309 N.E.2d at 739.

id. at 324,309 N.E.2d at 740 .

" No. 72-C-2104 (N.D. Ill. Aug. 18, 1975), noted in 7 Loy. CHI. L.J. 507 (1976).
} 
mony, the court held that the state could rationally choose to predict dangerousness without an overt act. ${ }^{65}$ The court feared the consequences of an overt dangerous behavior requirement:

There must always be a first dangerous act in any series of dangerous acts [of] a mentally ill person, and the due process clause does not render the state powerless to protect against that first dangerous act provided it establishes a test for determining dangerousness that is based on a rational appraisal of the scientific knowledge that is available. ${ }^{66}$

For a brief period North Carolina's statute required an "overt act" of dangerousness to support commitment. ${ }^{67}$ A 1974 amendment repealed the overt act requirement but increased the requisite burden of persuasion to "clear, cogent, and convincing evidence" of dangerousness. ${ }^{68}$ In re Salem ${ }^{69}$ was a challenge to the amended statute. The plaintiffs, relying on Lessard, argued that the statute was unconstitutionally vague and asked the court to read back into the statute an overt dangerous behavior requirement, but the North Carolina Court of Appeals disagreed, reasoning that the overt act standard was only one rational means of providing adequate evidence of dangerousness.

\section{Analysis of the Overt Dangerous Behavior Requirement}

\section{A. Preliminary Issues}

Before examining the rationales employed by the courts that have required proof of overt dangerous behavior as a constitutional prerequisite to involuntary civil commitment, it is necessary to consider several fundamental definitions and assumptions that underlie those rationales. These preliminary issues include the definitions of "dangerousness" and "overt dangerous behavior" and the questions whether "dangerousness" is a constitutional prerequisite to involuntary commitment and whether predictions of future danger-

is Id.

* Id. The vagueness challenge was also rejected, in part because of the practical impossibility of specifying the types of conduct that might lead to confinement. The argument that commitment constituted punishment for status was summarily disapproved.

One judge dissented, arguing that the prediction of violent behavior should be accompanied by a prior overt act. The dissent did not extend this reasoning to commitments based on an inability to survive in freedom.

67 N.C. GEN. S'tats. \& 122-58.3 (1974) (repealed 1974).

61973 N.C. Sess. Laws ch. 1408.

228 S.E.2d 649 (N.C. Ct. App. 1976). 
ousness are substantially more accurate if based on recent overt dangerous behavior.

1. Dangerousness. The definition of "dangerousness" is obviously crucial to any consideration of whether dangerousness or overt dangerous behavior is required for involuntary civil commitment. Yet defining "dangerousness," like defining "mental illness," has proven difficult for both courts and legislatures. Someone who is "dangerous" is likely to inflict harm, but the term "dangerous" by itself does not define the probability, object, or nature of the harm.$^{70}$ For example, a person might be very likely or only marginally likely to do harm. The danger might be imminent or merely a long-term probability. The object of the harm might be the person himself, other persons, his own property, or the property of others. The harm might involve various gradations of physical or psychological damage; it might result from the person's actions or his failure to act. All these dimensions of "dangerousness" are potentially relevant to whether a person is so "dangerous" that the state would be justified in committing him. Developing a less complicated definition of "dangerousness" that excludes or ignores any of these dimensions is problematic because the significance of any one factor (e.g., the type of harm) may depend on the other factors (e.g., the magnitude or probability of harm). For instance, the definition could be made nonspecific by limiting "dangerousness" to the likelihood of doing physical harm to persons; but a state might claim to have a greater interest in preventing extensive property damage that is highly probable than in preventing mild physical injuries that are only marginally probable.

Despite this difficulty, some courts and legislatures have attempted to make the term "dangerousness" less ambiguous by specifying the degree of probability and the type and magnitude of harm that they consider necessary to justify confining a mentally ill person against his will. The Donaldson Court's list of the "generally accepted" grounds for involuntary confinement of the mentally ill-" to prevent injury to the public, to insure the committed individual's own survival or safety, or to alleviate or cure his illness"11-suggests at least three types of dangers: (1) injưry to others, (2) active injury to self (e.g., suicide), and (3) passive injury to self (e.g., neglect). The Court did not mention injury to property (unless

70 See generally A. Brooks, Law, Psychiatry and the Mental Health System 680-82 (1974); Livermore, Malmquist \& Meehl, supra note 14, at 81-83; Note, Civil Commitment of the Mentally Ill: Theories and Procedures, 79 HaRv. L. Rev. 1288, 1289-95 (1966).

1422 U.S. at 573-74. 
this is subsumed under injury to the public) and did not distinguish between physical and psychological injury. Nor did the Court specify how substantial the injury must be, though by rejecting the state's interest in guaranteeing the mentally ill a minimum living standard and by distinguishing between dangerousness to self and the need for treatment the Court did imply that the potential injury to the individual himself must be rather substantial..$^{72}$ In contrast the Lessard court required "extreme likelihood that if the person is not confined he will do immediate harm to himself or others," and suggested that the potential harm must be "substantial." 33 Hawaii's statute provides a further comparison; the statute requires a substantial risk of physical or emotional injury to another or of physical injury to self or an attempt or threat imminently to damage property in a way that would constitute a crime. ${ }^{74}$ Hawaii's statute, however, has been held to violate due process by allowing dangerousness to property as a ground for commitment. ${ }^{75}$

Such general definitions of dangerousness are given further content by the nature of the evidence required to support a finding that a person is dangerous. The courts and legislatures that have required overt dangerous behavior to prove "dangerousness" have in effect supplemented their definitions of dangerousness by requiring that any predictions of future dangerousness be based on certain types of past behavior.

2. Overt Dangerous Behavior. There is no case law holding that a particular act does or does not constitute overt dangerous behavior, because the cases that have required the standard have all involved broad remedial orders that were not limited to the facts of a particular case. ${ }^{76}$ The cases therefore offer at best only general

72 Id. at 575-76.

${ }^{73} 349$ F. Supp. at 1093.

7 1976 Hawaii Sess. Laws Act 130, \& 1. See note 77 infra.

${ }^{75}$ Suzuki v. Yuen, 46 U.S.L.W. 2181 (D. Hawaii Sept. 26, 1977).

76 The leading case is typical. Lessard v. Schmidt, 349 F. Supp. 1078 (E.D. Wis. 1972), vacated and remanded for a more specific order, 414 U.S. 473 (1974), order on remand, 379 F. Supp. 1376 (1974), vacated and remanded on other grounds, 421 U.S. 957 (1975), order reinstated on ręmand, $413 \mathrm{~F}$. Supp. 1318 (1976), was a class action, which declared Wisconsin's statute unconstitutional för failing to provide all persons undergoing mental commitment procedures with written and oral notice informing them of the factual basis for their detention, their right to a jury trial, the standards upon which they may be detained, the names of examining physicians and all persons who may testify in favor of their continued detention, and a summary of the proposed testimony of those who may testify in favor of their commitment. Within 48 hours a judicial hearing is required to determine whether or not probable cause exists to believe these persons are both mentally ill and dangerous to themselves or others. For this hearing, counsel must be appointed sufficiently in advance to adequately prepare a defense; the person detained and members of his family who can be 


\section{definitions of overt dangerous behavior. The statutes, although far from uniform, that require overt dangerous behavior offer more de- tailed definitions, but significant ambiguities remain. ${ }^{77}$ Neverthe-}

located with reasonable diligence must be given notice; and the person detained has a nonwaivable right to be present and an opportunity to be heard. Persons detained must be informed of their right against self-incrimination. Within 14 days a full hearing on the necessity for commitment is required at which the person detained has the right to be represented by counsel and to be appointed counsel if indigent. The hearing must apply the rules of evidence including the hearsay rule. The privilege against self-incrimination will attach to psychiatric and other expert evidence. Proof beyond a reasonable doubt that the person detained is both mentally ill and dangerous is also required. The finding of dangerousness must be based on a recent act, attempt, or threat to do substantial harm. Before commitment all available less drastic alternatives to commitment must have been investigated and found beyond a reasonable doubt to be unsuitable. 379 F. Supp. 1376, 1378-79 (E.D. Wis. 1974) (order on remand), vacated and remanded on other grounds, 421 U.S. 957 (1975), order reinstated on remand, $413 \mathrm{~F}$. Supp. 1318 (1976).

$\pi$ If at the final hearing upon a petition seeking to commit a person to the custody of the State Department of Mental Health, the probate judge on the basis of substantial evidence shall find:

1. that the persons [sic] sought to be committed is mentally ill; and

2. that as a consequence of the mental illness the person poses a real and present threat of substantial harm to himself or to others; and

3. that the threat of substantial harm has been evidenced by a recent overt act; and

4. that treatment is available for the person's mental illness or that confinement is necessary to prevent the person from causing substantial harm to himself or to others; and

5. the probate judge shall enter an order setting forth his findings, granting the petition and ordering the person committed to the custody of the Alabama State Department of Mental Health.

1975 Ala. Acts 2562,2566 (Act No. 1226, § 10).

At the expiration of the 14-day period of intensive treatment any person who [has a] mental disorder . . . and who continues to present an imminent threat of taking his own life, may be confined for further intensive treatment pursuant to this article for an additional period not to exceed 14 days.

CaL. Welf. \& INST'NS CoDE $\$ 5260$ (West 1972).

At the expiration of the 14-day period of intensive treatment, a person may be confined for further treatment pursuant to the provisions of this article for an addditional period, not to exceed 90 days if he:

(a) Has threatened, attempted, or inflicted physical harm upon the person of another . . . and ... a as a result of mental disorder, presents an imminent threat of substantial physical harm to others....

Id. at $\$ 5300$.

"Dangerous to others" means likely to do substantial physical or emotional injury on another, as evidenced by a recent act, attempt or threat.

"Dangerous to self" means likely to do substantial physical injury to one's self, as evidenced by a recent act, attempt or threat to injure one's self physically or by neglect or refusal to take necessary care for one's own physical health and safety together with incompetence to determine whether treatment for mental illness or substance abuse is appropriate.

"Dangerous to property," in the context of an emergency admission, means inflicting, attempting or threatening imminently to inflict damage to any property in a manner which constitutes a crime, as evidenced by a recent act, attempt or threat.

1976 Hawaii Sess. Laws Act $130, \S 1$. Dangerousness to property, however, was held not to be a constitutional basis for commitment. Suzuki v. Yuen, 46 U.S.L.W. 2181 (D. Hawaii Sept. $26,1977)$. 


\title{
less, the statutes and cases are in accord on most important points, ${ }^{78}$
}

\begin{abstract}
"Likelihood of serious harm," (1) a substantial risk of physical harm to the person himself as manifested by evidence of threats of, or attempts at, suicide or serious bodily harm; (2) a substantial risk of physical harm to other persons as manifested by evidence of homicidal or other violent behavior or evidence that others are placed in reasonable fear of violent behavior and serious physical harm to them; or (3) a very substantial risk of physical impairment or injury to the person himself as manifested by evidence that such person's judgment is so affected that he is unable to protect himself in the community and that reasonable provision for his protection is not available in the community.
\end{abstract}

Mass. Gen. Laws AnN. ch. 123, $§ 1$ (West 1972).

Mentally ill dangerous person shall mean any mentally ill person who presents:

(1) A substantial risk of serious harm to another person or persons within the near future, as manifested by evidence of recent violent acts or threats of violence or by placing others in reasonable fear of such harm; or

(2) A substantial risk of serious harm to himself within the near future, as manifested by evidence of recent attempts at, or threats of, suicide or serious bodily harm, or evidence of inability to provide for his basic human needs, including food, clothing, shelter, essential medical care, or personal safety.

Neb. Rev. Stat. § 83-1009 (1976).

Any person who, by reason of the commission of overt acts, is determined by a qualified physician to be violent and of imminent danger to himself or others, or to be gravely disabled, may be taken into custody by a law-enforcement officer as authorized by this section. Authorization may be given by any qualified physician in the form of a written statement that he has made a personal examination of the person within 24 hours of the date of his statement and that it is his professional opinion, based upon such examination, that the person is violent and of imminent danger to himself or others, or is gravely disabled. The written statement of the qualified physician must specify the overt acts upon which his professional opinion is based.

N.C. GEN. Stat. \& 122-58.3 (1974) (repealed 1974).

A law enforcement officer may take an individual into custody for up to 48 hours, exclusive of Saturdays, Sundays and legal holidays, if he or she has cause to believe that such individual is mentally ill, is a drug dependent, or is developmentally disabled, and the individual exhibits conduct which constitutes a substantial risk of physical harm to the individual or to others. The officer's belief shall be based on specific and recent acts, attempts or threats to act made by the subject individual as observed by the officer or by other persons.

Wis. Stat. Ann. § 51.15(1) (West Supp. 1977) (emergency detention).

Every written petition for examination shall allege that the subject individual to be examined:

1. Is mentally ill, drug dependent, or developmentally disabled and is a proper subject for treatment; and either

2. Is dangerous because of:

a. A substantial risk of physical harm to the subject individual as manifested by evidence of recent threats of or attempts at suicide or serious bodily harm; or

b. A substantial risk of physical harm to other persons as manifested by evidence of recent homicidal or other violent behavior, or by evidence that others are placed in reasonable fear of violent behavior and serious physical harm to them, as evidenced by a recent overt act, attempt or threat to do such physical harm; or

3. Evidences a very substantial risk of physical impairment or injury to the subject individual, as manifested by evidence that his or her judgment is so affected that he or she is unable to protect himself or herself in the community and that reasonable provision for his or her protection is not available in the community and the individual is not appropriate for placement under $\S 55.06$. The subject individual's status as a minor does not automatically establish dangerousness under this subparagraph.

Id. $\S 51.20$ (1) (a) (involuntary commitment for treatment).

${ }^{28}$ One statute provides a significantly broader range of dangerousness by allowing that 
so it is possible to construct a general definition of overt dangerous behavior.

Overt dangerous behavior is behavior that could reasonably be regarded as presenting a risk of substantial physical harm to others or to the actor, or as demonstrating an inability to survive in freedom. Dangerousness depends not on whether a person intends to cause harm but on whether others might reasonably regard his behavior as likely to cause harm. The behavior need not be a completed act. An attempt or threat, or even a failure to act may suffice. Further, the cases and statutes have implied that the behavior itself must be dangerous, not simply some evidence to support a finding of dangerousness. As one court said, "It must be shown that [the person] has actually been dangerous in the recent past."79

Because there is no case law elucidating the content of overt dangerous behavior, it will be helpful to "invent" a body of case law by testing the definition of overt dangerous behavior against a series of hypothetical situations. The hypotheticals are organized to consider first the danger of harming others, then the danger of suicide or self-injury, and finally the danger of being unable to care for oneself. For the purposes of these hypothetical situations, assume that Smith is resisting commitment and that a competent psychiatrist has determined that Smith is mentally ill and likely to be dangerous.

Smith assaults his spouse with a butcher knife and wounds her. This behavior clearly meets the definition because it endangers his spouse. If Smith stabs at his spouse but misses, this attempt also presents a risk of substantial harm. Suppose Smith believes the butcher knife is a butter knife and thus cannot hurt his spouse. This still constitutes overt dangerous behavior because Smith's spouse is in fact endangered, no matter what Smith believes. Smith reveals to a third person his elaborate plan to kill his spouse. This threat, if objectively a serious one, also could support a finding of overt dangerous behavior. In a fit of rage Smith smashes a platter on the floor. Smith's spouse may fear that the next furious act will result in harm to her, but Smith's behavior is not dangerous because by

substantial emotional injury or damage to property which constitutes a crime may provide a basis for commitment. 1976 Hawaii Sess. Laws Act 130, $\S 1$. The basis of dangerousness to property was held not to meet substantive due process. Suzuki v. Yuen, 46 U.S.L.W. 2181 (D. Hawaii Sept. 26, 1977) (the proper standard requires imminent and substantial danger evidenced by a recent overt act, attempt, or threat).

7 Lynch v. Baxley, 386 F. Supp. 378, 391 (M.D. Ala. 1974). 
itself it presents no risk of physical harm to the spouse. Because a psychiatrist has pronounced Smith mentally ill, this result may seem troubling, but the overt dangerous behavior requirement has not yet been met.

Smith slits his wrists. This behavior is within the definition because it is an apparent suicide attempt. But suppose Smith declares his intent to kill himself. Whether this is dangerous behavior depends on whether another person could reasonably regard Smith's threats as serious. Smith is a chronic alcoholic and has a depressive mental disorder. Although Smith is statistically a high suicide risk, there is as yet no dangerous behavior, unless Smith's consumption of alcohol is regarded as presenting a substantial risk of harm to himself. Although the statutes and cases do not give much guidance, they seem to require a more proximate danger than alcohol consumption presents.

Smith is catatonic. His behavior constitutes overt dangerous behavior because it manifests his inability to care for his health or safety. Smith is not catatonic, but he hasn't eaten in many days. If this failure to eat is the result of neglect, the overt dangerous behavior standard is satisfied because Smith's conduct demonstrates his inability to care for his health. What if Smith's fast is the result of an intentional decision? Although a sane person may for his own reasons fast without the conduct being regarded as dangerous, Smith's mental illness colors his conduct considerably. It is difficult to say whether this conduct is overt dangerous behavior. Smith refuses medication. If the medication is needed to maintain his life or prevent a debilitating condition, Smith's refusal is dangerous behavior because it endangers his health. This conduct is like fasting in that the refusal to take medication might be the result of a knowing and intentional decision, but the health threat is more proximate. Smith is hyperactive and compulsively repeats one task. A psychiatrist might predict that the mental disorder will ultimately be disabling, but the behavior does not meet the definition because it does not show that Smith is currently unable to care for himself.

These hypotheticals indicate that the generally adopted definition of overt dangerous behavior is adequate to settle some cases, but leaves some troubling ambiguities that will have to be resolved by further litigation or more specific legislation.

3. Is Dangerousness Required for Involuntary Civil Commitment? Since the essential function of an overt dangerous behavior requirement is to establish a minimum level of support for a finding that a person is "dangerous," the importance of the requirement depends on whether and when a finding of dangerousness 
is itself a prerequisite to involuntary commitment. The Supreme Court in Donaldson indicated that the Constitution required a finding of at least one of the "generally advanced" grounds for civil commitment-a risk of harm to self or others, an inability to survive safely in freedom, or the need for treatment to alleviate or cure a disease. The Court refused to decide, however, whether any one of these justifications by itself would be sufficient, or indeed whether any two or even all three together would be sufficient. ${ }^{80}$

Several lower courts have gone beyond Donaldson by holding that the Constitution always requires a finding of "dangerousness" before involuntary civil commitment. ${ }^{81}$ As indicated above, the definition of "dangerousness" generally adopted by the lower courts includes both the likelihood of physical harm to self or others and the inability to survive safely in freedom (which may be viewed as a form of risk of harm to self).$^{82}$ On the other hand, the generally accepted definition of "dangerousness" does not include the need for treatment. Therefore, by requiring proof of "dangerousness" in all cases, these courts have in effect held that a need for treatment is not an independent ground for commitment. ${ }^{83}$

The question whether the need for treatment by itself should be a constitutionally acceptable ground for involuntary civil commitment merits further consideration because the answer could have a significant impact on the number of cases where a finding of "dangerousness" is constitutionally required. Donaldson indicates that the answer should be determined by due process interest balancing, that is, by weighing the state's interest in commiting an individual against the individual's interest in freedom.

The Supreme Court has suggested at least once that treatment may be a sufficient ground for commitment. In Robinson $v$. California ${ }^{84}$ the Court in dicta approved a program of compulsory treatment for narcotics addicts that included periods of involuntary confinement. ${ }^{85}$ But the Robinson dictum does not establish a principle that treatment may in all cases justify commitment. The narcotics addict is unlike the nondangerous mentally ill person because

sor a discussion of a case where the Court has sustained the grounds relied on by the government in committing a person, see notes 20 \& 31 supra.

"se See text and notes at notes $35-60$ supra.

"2 See O'Connor v. Donaldson, 422 U.S. 563, 574 n.9 (1975).

${ }^{23}$ Of course, the consequences of nontreatment may be so severe that a person who refuses treatment will be found "dangerous," but the ground for commitment in such a case is "dangerousness," not the mere need for treatment.

st 370 U.S. 660 (1962).

s $I d$. at 665 . 
the narcotics addict threatens violation of the narcotics laws. Treatment and confinement may be justified in this context because the state's interests are substantial. Further, the individual's narcotics habit may threaten his own safety or survival. On the other hand, the nondangerous mentally ill person by definition poses no risk of harm to others or himself. Thus, the balance of interests could plausibly weigh in favor of the individual when the state's only interest is in providing treatment. Indeed, Chief Justice Burger, concurring in Donaldson, expressly rejected "the theory that a State may lawfully confine an individual thought to need treatment and justify that deprivation of liberty solely by providing some treatment," concluding that "[o]ur concepts of due process would not tolerate such a "trade-off." "s6

Other factors, however, suggest that the need for treatment should be sufficient to justify involuntary confinement of the mentally ill in at least some instances. Treatment is distinguishable from simply improving an individual's living standard because treatment seeks to remove the condition that allows intervention. Treatment may be established as a limited intervention that will cease when a cure is effected or when, at the end of a definite period, no improvement is obtained.

The most difficult factor to weigh in the balance is the prospect of curing or improving the mental illness. Drug treatments today offer many patients the possibility of significant improvement. ${ }^{87}$ The consequent infringement of liberty may last only a few weeks or months. The balance is difficult to weigh, but the categorical judgment that the benefit of treatment may never outweigh the individual's liberty interest seems unwarranted. The remarkable advances that have been made in drug therapy suggest not only that involuntary treatment may sometimes be justified, but that the possibility of further advances should not be foreclosed by legal rules. ${ }^{88}$

There is a significant possibility for abuse in allowing involuntary commitment solely on the basis of a psychiatric judgment that a person needs treatment, but forbidding all commitments of nondangerous persons is not necessary in order to curb this abuse.

422 U.S. at 589 (Burger, C.J., concurring).

${ }^{87}$ See generally Berger, Hamburg \& Hamburg, Mental Health; Progress and Problems, Daedalus, Winter 1977, at 261.

${ }^{88}$ For a different weighing of this balance, see DuBose, Of the Parens Patriae Commitment Power and Drug Treatment of Schizophrenia: Do the Benefits to the Patient Justify Involuntary Treatment? 60 MINN. L. REv. 1149 (1976). 
Rather, commitment for treatment could be limited to situations where abuse is unlikely. For example, it would be appropriate to require that efficacious treatment be available, and that it be administered without confinement if possible. Further, since mental disorders may range from severe to relatively innocuous, it would be appropriate to recognize that at some point the mental illness is not severe enough to warrant involuntary treatment. If the need-fortreatment rationale is limited in this fashion, it will not become a "loophole" and the "dangerousness" rationale will remain important.

4. Overt Dangerous Behavior and Accurate Predictions of Future Dangerous Behavior. A basic assumption underlying the rationales for an overt dangerous behavior requirement is that predictions that an individual will be dangerous in the future are more accurate if based on specific instances of dangerous behavior in the past by the same individual. A special concern for predictive accuracy in this context is understandable; involuntary commitment imposes a "massive curtailment of liberty" has done in the past, but for what he might do in the future if not committed. Yet predictions of dangerousness are notoriously inaccurate.

The relevant studies have almost all focused on the prediction of danger to others. ${ }^{90}$ These studies reveal that dangerousness is commonly overpredicted. The highest rate of accurate prediction of future dangerous behavior has been approximately $35 \%^{91}$-in other words, only $35 \%$ of the persons labeled dangerous actually exhibited dangerous behavior in the future..$^{22}$ Commentators have suggested

s Humphrey v. Cady, 405 U.S. 504, 509 (1972).

" Kozol, Boucher \& Garofalo, The Diagnosis and Treatment of Dangerousness, $18 \mathrm{~J}$. Crime \& Delinquency 371 (1972); Rubin, Predictions of Dangerousness in Mentally Ill Criminals, 27 ARCH. Gen. Psych. 397 (1972); Wenk, Robison \& Smith, Can Violence Be Predicted?, 18 J. Crime \& Delinquency 393 (1972). See also Megargee, The Prediction of Violence With Psychological Tests, in Current Topics In Cunical \& Community Psychology (C. Spielberger ed. 1970). For good overviews of prediction of violence, see Monahan, The Prediction of Violence, in VIOLEnCE AND CRIMinal Justice 15 (D. Chappell \& J. Monahan eds. 1975); Ennis \& Litwack, Psychiatry and the Presumption of Expertise: Flipping Coins in the Courtroom, 62 CALIF. L. REv. 693 (1974). The release of nearly 1,000 mental patients following the Supreme Court's decision in Baxtrom v. Herold, 383 U.S. 107 (1966), occasioned several follow-up reports on prediction of dangerousness. See, e.g., Steadman \& Keveles, The Community Adjustment and Criminal Activity of the Baxtrom Patients-1966-1970, in 129 AM. J. PsYch. 304 (1972).

" Kozol, Boucher \& Garofalo, supra note 90, at 390.

22 It is important to recognize that erroneous predictions involve two types of errors. A person can be falsely predicted to be dangerous (false positive prediction) or he can be falsely predicted to be not dangerous (false negative prediction). Wilkins, The Case for Prediction, in 3 Crime AND Justice 375 (L. Radzinowitz \& M. Wolfgang eds. 1971). The empirical studies 
several reasons why predictions of danger to others are so inaccurate. First, the person predicting dangerousness is not likely to learn of incorrect positive predictions since those persons determined to be dangerous are typically confined. ${ }^{93}$ Many prediction makers may consider the consequences of failing to incarcerate a dangerous person more serious than the consequences of incarcerating a nondangerous person. ${ }^{94}$ Others may regard the requirement of a prediction of dangerous behavior as simply an expedient to get someone to treatment ${ }^{95}$ or may believe that in a close case it is better to treat than to fail to treat for a problem. ${ }^{96}$ Most importantly, dangerous behavior is rare conduct, and predicting the occurrence of rare conduct is very difficult. ${ }^{97}$

Several studies have noted that predictions of dangerousness that are based on overt dangerous behavior are more accurate than other predictions. One study emphasized that " $[t]$ he difficulty in the prediction of dangerousness is immeasurably increased when the subject has never actually performed an assaultive act."98 The study concluded, "Given the present reality it is unlikely that dangerousness can be predicted in a person who has not acted in a dangerous or violent way."99 Another study said flatly, "No one can predict dangerous behavior in an individual with no history of acting out." 100 These studies suggest that an overt dangerous behavior requirement will help ensure that fewer nondangerous persons are committed, but no study has yet attempted to determine the actual extent to which such a requirement would reduce false predictions of dangerousness.

The prediction of dangerousness to self has not received equivalent empirical scrutiny. But, as with dangerousness to others, it is probable that prediction based on overt dangerous behavior would increase predictive accuracy. There is a common sense notion that

of prediction have focused on false positives to the exclusion of false negatives. Any attempt to reduce the number of false positive predictions will increase the number of false negatives, although because rare conduct is involved, the increase in false negatives will not be as large as the decrease in false positive predictions.

${ }^{3}$ Dershowitz, Psychiatry in the Legal Process: A Knife That Cuts Both Ways, Trial, Feb./Mar. 1968, at 29, 33.

" Monahan, supra note 90, at 22-23.

${ }^{95}$ Rubin, supra note 90.

"B Ennis \& Litwack, supra note 90, at 720-21.

${ }^{97}$ Dewshowitz, The Law of Dangerousness: Some Fictions About Predictions, 23 J. LEG. Educ. 24, 46 (1970); Gottfredson, Assessment of Methods, 3 Crime ANd Justice 343, 352 (L. Radzinowicz \& M. Wolfgang eds. 1971).

${ }^{88}$ Rubin, supra note 90 , at 400 .

${ }^{29}$ Id. at 405 .

100 Kozol, Boucher \& Garofalo, supra note 90, at 384. 
people will continue to behave as they have already behaved, and an overt dangerous behavior requirement embodies this intuition. ${ }^{101}$

There is some reason to believe, however, that reliance on overt dangerous behavior will be less helpful for predictions of dangerousness to self than for predictions of dangerousness to others. First, dangerousness to self includes an inability to care for oneself. Compared to the assaultive conduct needed to show dangerousness to others, the neglect or absent-mindedness needed to show an inability to care for oneself is probably more common behavior. An overt dangerous behavior requirement may thus screen out fewer individuals falsely predicted to be dangerous to themselves. Second, overt dangerous behavior may be significantly misleading as a predictor of suicide. The relevant behavior is threatened or attempted suicide. Yet not only do many successful suicides occur with no prior threats or attempts, but many persons threaten or attempt suicide without intending to kill themselves. ${ }^{102}$

The relationship between overt dangerous behavior and predictions of dangerousness can thus be summarized as follows: there is some evidence to support the common sense notion that predictions based on past behavior are more accurate than other predictions, at least where danger to others is involved, but there is as yet no reliable estimate of how much better predictions based on past behavior are, and all predictions of dangerousness are more likely to be incorrect than to be accurate.

\section{B. The Arguments in Favor of an Overt Dangerous Behavior Requirement}

The courts that have confronted the argument for an overt dangerous behavior requirement have considered four distinct

101 One commentator has relied on this common sense expectation in arguing for an overt dangerous behavior requirement, see Ennis \& Litwack, supra note 90, at 749: "One of the most fundamental assumptions we make about life is that the future will be pretty much like the past. People who have controlled their behavior in the past can probably be expected to control their behavior in the future. Although this assumption is sometimes wrong, it is correct often enough so that it affords a more rational basis for predicting dangerousness than the present reliance on psychiatric judgments." Ennis has repeatedly advocated an overt dangerous behavior requirement. See Ennis, Civil Liberties and Mental Illness, 7 Crm. L. Bull. 101, 112 (1971); Ennis, Mental Illness, 1969-70 Annual Survey of American Law 29, 46 (1970).

The National Institute for Mental Health's proposal for model legislation adopted an overt dangerous behavior requirement in order to "give credence to the reasonable expectation that people who have restrained aggressive or violent impulses in the past can be expected to continue to do so."

${ }^{102}$ Center for Studies of Suicide Prevention, National Institute of Mental Health, Suicide Prevention in the 70s, at 91 (DHEW Pub. No. 72-9054, 1973). 
grounds for the requirement: sufficiency of the evidence, vagueness, punishment for status, and due process interest balancing.

1. Sufficiency of the Evidence. The concept of sufficiency of the evidence allows the judge to declare as a matter of law that the evidence presented cannot support a certain factual conclusion. In Lynch v. Baxley ${ }^{103}$ the district court relied on the absence of sufficient evidence in holding that overt dangerous behavior was necessary to support an involuntary commitment. The sufficiency-of-theevidence analysis relies directly on the utility of overt dangerous behavior in predicting future dangerous behavior. The court in Lynch argued that without some behavior there is no direct evidence of dangerousness-only a "mere expectancy" based on opinion and conjecture, which "does not rise to the level of legal significance." 104

The sufficiency-of-the-evidence approach is appealing, particularly when a burden of proof greater than a preponderance is required for commitment. ${ }^{105}$ But this analysis does not reach constitutional dimensions. Indeed, the court in Lynch may have intended the overt dangerous behavior requirement as a common law standard of dangerousness rather than a constitutional principle. Although the court invoked constitutional arguments elsewhere in its

${ }^{103} 386$ F. Supp. 378 (M.D. Ala. 1974).

104 Id.

${ }_{105}$ Many courts and legislatures have viewed the preponderance burden of proof as inadequate to protect the individual's liberty interest, although courts have disagreed as to what increased burden of proof is appropriate. Some courts have required proof beyond a reasonable doubt. United States ex rel. Stachulak v. Coughlin, 520 F.2d 931, 936-37 (7th Cir. 1975); In re Ballay, 482 F.2d 648 (D.C. Cir. 1973); Suzuki v. Quisenberry, 411 F. Supp. 1113, 1132 (D. Hawaii 1976); Lessard v. Schmidt, 349 F. Supp. 1078, 1094-95 (E.D. Wis. 1972), vacated and remanded for a more specific order, 414 U.S. 473 (1974), order on remand, 379 F. Supp. 1376 (1974), vacated and remanded on other grounds, 421 U.S. 957 (1975), order reinstated on remand, 413 F. Supp. 1318 (1976); cf. In re Pickles, 170 So. 2d 603, 612 (Fla. Dist. Ct. App. 1965) ("extreme care should be exercised in adjudicating one incompetent"). Other courts have preferred to compromise between the preponderance and beyond a reasonable doubt burdens of proof, generally requiring that the evidence be clear and convincing. Fippett v. Maryland, 436 F.2d 1153, 1158 (4th Cir. 1971); Stamus v. Leonhardt, 414 F. Supp. 439 (S.D. Iowa 1976); Doremus v. Farrell, 407 F. Supp. 509, 516-17 (D. Neb. 1975); Bartley v. Kremens, 402 F. Supp. 1039, 1051-53 (E.D. Pa. 1975), remanded for reconsideration of class certification, 97 S. Ct. 1709 (1977); Dixon v. Attorney Gen., 325 F. Supp. 966, 974 (M.D. Pa. 1971); People v. Sansone, 18 Ill. App. 3d 315, 325, 309 N.E.2d 733, 740-41 (1974); cf. United States v. Brown, 478 F.2d 606 (D.C. Cir. 1973) (dictum) (defendant had been acquitted by reason of insanity); In re Valdez, 540 P.2d 818 (N.M. 1975) (civil commitment of individual found incapable to stand criminal trial); Fhagen v. Miller, 65 Misc. 2d 263, 317 N.Y.S.2d 128 (1970) ("civil standard" applies to requests for relief following emergency admission), modified on other grounds, 36 App. Div. 2d 926, 321 N.Y.S.2d 61 (1971); State ex rel. Hawks v. Lazaro, 202 S.E.2d 109 (W. Va. 1974) (emergency commitment). See generally Woodby v. Immigration \& Naturalization Serv., 385 U.S. 276, 284-86 (1966) (deportation, although not criminal, demands a higher standard of proof than preponderance of the evidence). 
opinion, in requiring an overt dangerous behavior standard the court spoke simply of sufficiency of the evidence being a "legal question." 106

2. Vagueness. The vagueness doctrine requires that conduct that can lead to incarceration be described with reasonable specificity ${ }^{107}$ Although the doctrine is commonly applied to criminal proceedings, the underlying rationale of the doctrine is applicable to civil commitment, which results in a similar deprivation of liberty. The Supreme Court has repeatedly noted that the labeling of a proceeding as civil or criminal does not control the applicability of due process rights. ${ }^{108}$ The Court has accordingly applied the vagueness doctrine to noncriminal statutes on several occasions. ${ }^{109}$ Most courts have agreed that the vagueness doctrine applies to civil commitment, ${ }^{110}$ and several courts that have required overt dangerous behavior have considered the vagueness argument, at least in regard to the constitutional basis of a dangerousness standard."11

The vagueness doctrine serves two primary purposes. First, a statute must be definite in order to give fair notice of what conduct is forbidden. ${ }^{112}$ Second, a statute must give adequate guidance to those who enforce it in order to prevent the risk of arbitrary and discriminatory enforcement. ${ }^{113}$ Clear statutory language also helps

104386 F. Supp. at 391 ,

${ }^{107}$ See, e.g., United States v. Harriss, 347 U.S. 612, 617 (1954); Bouie v. City of Columbia, 378 U.S. 347, 350-51 (1964). See generally Note, The Void-for-Vagueness Doctrine in the Supreme Court, 109 U. PA. L. Rev. 67 (1960).

${ }^{108}$ In re Winship, 397 U.S. 358, 365-66 (1970); In re Gault, 387 U.S. 1, $49-50$ (1967).

$10 \%$ See, e.g., Boutilier v. Immigration \& Naturalization Serv., 387 U.S. 118, 123 (1967) (deportation for "affliction with a psychopathic personality"); Giaccio v. Pennsylvania, 382 U.S. 399, 402 (1966) (assessment of court costs to acquitted defendants); Jordan v. DeGeorge, 341 U.S. 223, 231 (1951) (deportation for conviction of crime "involving moral turpitude" not void for vagueness of standard).

"Even the courts rejecting an overt dangerous behavior requirement have accepted that the vagueness doctrine applies to involuntary civil commitment. See United States ex rel. Mathew v. Nelson, No. 72-C-2104 (N.D. Ill. Aug. 18, 1975); In re Salem, 228 S.E.2d 649, 651 52 (N.C. Ct. App. 1976) (finding statute not unconstitutionally vague).

i' Stamus v. Leonhardt, 414 F. Supp. 439 (S.D. Iowa 1976); Doremus v. Farrell, 407 F. Supp. 509 (D. Neb. 1975); Bell v. Wayne County Gen. Hosp., 384 F. Supp. 1085 (E.D. Mich. 1974); Lessard v. Schmidt, 349 F. Supp. 1078 (E.D. Wis. 1972), vacated and remanded for a more specific order, 414 U.S. 473, order on remand, 379 F. Supp. 1376 (1974), vacated and remanded on other grounds, 421 U.S. 957 (1975), order reinstated on remand, $413 \mathrm{~F}$. Supp. 1318 (1976); Commonwealth ex rel. Finken v. Roop, 234 Pa. Super. Ct. 155, 339 A.2d 764 (1975).

112 Papachristou v. City of Jacksonville, 405 U.S. 156, 162-68 (1972); Lanzetta v. New Jersey, 306 U.S. 451, 453 (1939); Cline v. Frink Dairy Co., 274 U.S. 445, 458 (1927); Connally v. General Constr. Co., 269 U.S. 385, 391 (1926); United States v. L. Cohen Grocery Co., 255 U.S. 81,89 (1921).

III Papachristou v. City of Jacksonville, 405 U.S. 156, 168 (1972); Thornhill v. Alabama, 310 U.S. 88, 97-98 (1940). See also Niemotko v. Maryland, 340 U.S. 268, 285 (1951) (Frankfurter, J., concurring). 
provide for judicial review that can effectively regulate the administration of the law. ${ }^{114}$

It could be urged that a commitment statute that does not require overt dangerous behavior fails to give fair notice of what conduct will result in a loss of liberty. This argument, however, pushes the concept of fair notice beyond its logical bounds. The individual is not committed because of his conduct, but rather because of his status as a mentally ill and dangerous person. The overt behavior is merely evidence of this status. When a statute looks to characteristics rather than conduct, the vagueness rationale does not apply. In Boutilier v. Immigration \& Naturalization Service ${ }^{115}$ the Supreme Court considered a section of a statute excluding from entry to the country any alien with a "psychopathic personality." The Court said, "The section imposes neither regulation of nor sanction for conduct. In this situation, therefore, no necessity exists for guidance so that one may avoid the applicability of the law."116

In contrast, the second purpose of the vagueness doctrine, the avoidance of arbitrary and discriminatory enforcement, has potential application. Civil commitment determinations typically rely heavily on psychiatric diagnosis and prediction, thus inviting arbitrary results because psychiatrists have a low rate of agreement. ${ }^{117}$

A commitment statute that required overt dangerous behavior would probably not be impermissibly vague. In Minnesota ex rel. Pearson v. Probate Court ${ }^{118}$ the Supreme Court examined a statute that allowed involuntary confinement of dangerous sexual psychopaths. The state courts had construed that statute to require a habitual course of misconduct in sexual matters. ${ }^{19}$ This conduct had to manifest the person's inability to control his behavior and the likelihood that he would harm others. In light of this construction the court sustained the statute against a challenge of vagueness, emphasizing that "the underlying conditions, calling for

11 Note, The Void-For-Vagueness Doctrine in the Supreme Court, 109 U. PA. L. REv. 67, 89 (1960).

${ }^{115} 387$ U.S. 118 (1967).

${ }^{116}$ Id. at 123.

117 Ennis \& Litwack, Psychiatry and the Prediction of Dangerousness: Flipping Coins in the Courtroom, 62 CALIF. L. REv. 693 (1974).

Psychiatrists may also be prone to bring personal biases into the determination, for example by finding that blacks more than whites or men more than women are likely to be violent. T. Szasz, The Manufacture of Madness (1970); Rubin, Prediction of Dangerousness in Mentally Ill Criminals, 27 ARch. Gen. Psych. 397, 398 (1972). But see A. Stone, Mental HEALTH AND THE LaW: A System IN TRANSITION 34-35 (1975).

I1K 309 U.S. 270 (1940).

"1' Id. at 273. 
evidence of past conduct pointing to probable consequences are as susceptible of proof as many of the criteria constantly applied in prosecutions for crime." 120 Commitment statutes are closely analogous to the statute at issue in Pearson. Thus, Pearson is a persuasive precedent that a statute providing for commitment of dangerous persons is not impermissibly vague if it requires evidence of overt dangerous behavior.

Nevertheless, the vagueness argument only allows a court to uphold a statute that requires overt dangerous behavior or, at most, to read such a requirement into a statute in order to avoid finding the statute unconstitutional. It does not mean that overt dangerous behavior is constitutionally required, since other means could be chosen to confine the otherwise unstructured judgments of psychiatrists and courts. For example, requiring psychiatrists to give detailed reasons for the determination of dangerousness, subject to review for reasonableness, might reduce the incidence of arbitrary or discriminatory commitment decisions. Similarly, a requirement that some behavior, not necessarily dangerous in itself, must be shown to support the classification of a person into a group with a certain likelihood of dangerousness might help minimize arbitrary or discriminatory commitment.

3. Punishment for Status. In Robinson v. California ${ }^{121}$ the Supreme Court required criminal sanctions to be predicated on an illegal act; otherwise the punishment is for status and is impermissible under the eighth amendment's proscription of cruel and unusual punishment. The Court in Robinson appeared to exclude civil confinement of the mentally ill from the scope of its holding:

It is unlikely that any State at this moment in history would attempt to make it a criminal offense for a person to be mentally ill, or a leper, or to be afflicted with a veneral disease. A State might determine that the general health and welfare require that the victims of these and other human afflictions be dealt with by compulsory treatment involving quarantine, confinement or sequestration. ${ }^{122}$

Justice Douglas' concurring opinion similarly distinguished crimi-

120 Id. at 274 (emphasis added).

121 370 U.S. 660 (1960) (state statute making it a misdemeanor punishable by imprisonment to "be addicted to narcotics" held unconstitutional). See also Powell v. Texas, 392 U.S. 514,532 (1968), (statute prohibiting appearing in a public place in a state of intoxication not a punishment for status, as appearing drunk in public constitutes an act, unlike the status of addiction in Robinson).

122370 U.S. at 666 (emphasis added). 
nal from noncriminal confinement: "The addict is a sick person. He may of course be confined for treatment or for the protection of society." 123 Thus, Robinson is on its facts limited to criminal punishment for status, and the Court suggested in dictum that status may properly be used as a criterion for other kinds of confinement.

Nonetheless, in Jackson $v$. Indiana the majority remarked, in dictum, that "considering the number of persons affected by involuntary commitment of the mentally ill, it is perhaps remarkable that the substantive constitutional limitations have not been more frequently litigated," 124 citing Robinson and Powell $v$. Texas, ${ }^{125}$ another case dealing with punishment for status. Thus, the Court has suggested, in a tantalizing but enigmatic fashion, that substantive constitutional limitations on civil commitment could be based on the punishment-for-status doctrine articulated in Robinson and Powell. Donaldson was the first case to result in any substantive constitutional limitation on the standards for civil commitment, and the Court's narrow holding did not reach the punishment-forstatus issue.

Although some litigants have urged the applicability of the punishment-for-status rationale, no court that has required overt dangerous behavior has relied on this rationale. ${ }^{126}$ This reluctance is understandable. Despite its similarity to criminal incarceration, involuntary commitment is not punitive in purpose. ${ }^{127}$ More important, even if the doctrine were to apply to civil commitment, an

123 Id. at 676.

124406 U.S. 715, 737 (1972). Jackson involved a challenge of Indiana's statute which allowed the civil commitment of accused persons who lacked the capacity to stand trial. Persons committed under this statute were allowed substantially fewer procedural and substantive rights than those committed under provisions regarding the feeble-minded or insane who had not been accused of crimes. The court found that this disparity was inconsistent with equal protection and found the protections in the former statute inadequate to satisfy due process.

125392 U.S. 514 (1968).

${ }^{126}$ In People v. Sansone, 18 Ill. App. 3d 315, 324, 309 N.E.2d 733, (1974), the court summarily rejected the punishment-for-status argument, distinguishing criminal incarceration from civil commitment involving treatment. The Illinois statute required treatment for all involuntarily committed patients. The federal court in United States ex rel. Mathew v. Nelson, No. 72-C-2104 (N.D. I1., Aug. 18, 1975), also considered a punishment-for-status challenge to the Illinois statute. The challenge was rejected on the basis that commitment was based not on the status of mental illness, but rather on the reasonable expectation of future dangerous behavior. This reasoning is unconvincing: dangerousness should be viewed as a status because dangerousness, by itself, does not require any conduct. Thus, no court has squarely considered and rejected a punishment-for-status analysis applied to statutes where treatment is not required, and where the status character of dangerousness is acknowledged.

${ }^{127}$ For a further discussion of the inapplicability of the punishment-for-status doctrine to civil commitment, see Developments-Civil Commitment, supra note 6, at 1259-64. 
overt dangerous behavior requirement would not cure the objectionable nature of the commitment, because overt behavior is only evidentiary of the status of dangerousness, and commitment would therefore still be based on status.

4. Due Process Interest Balancing. The most frequently invoked constitutional ground for an overt dangerous behavior requirement is the approach suggested in Donaldson-due process interest balancing. Substantive due process demands that the state's interest in confinement outweigh the individual's interest in remaining at liberty in order to justify civil commitment. The implementation of this requirement demands a balancing test-commitment should be allowed only when the magnitude of the harm feared times the probability of its occurrence is greater than the burden caused by the committed individual's loss of liberty. ${ }^{128}$ The magnitude of harm gauges the type of danger that is feared. The probability of the harm occurring gauges the degree of risk. The deprivation of the individual's liberty is the burden imposed to prevent the harm's occurrence, and the burden increases with the duration of the commitment. The factors are obviously not susceptible to accurate quantification. Nonetheless, the balancing test formulation focuses attention on the competing values at stake in the commitment decision.

The three-judge court in Lessard v. Schmidt ${ }^{129}$ employed a due process analysis that imputed certain rough approximations of weights to the variables. It regarded the individual's liberty interest as "fundamental." 130 In order to counterbalance a fundamental interest, the state's interest must be "compelling."'31 The court reasoned that the state's interest could not be compelling unless the degree of risk was very high.

The argument for requiring overt dangerous behavior to assure that the probability of future dangerous behavior is sufficiently high focuses on the known unreliability of predictions of dangerous behavior. The argument urges that commitment should be permitted only when prediction is most likely to be correct and that predictions based on overt dangerous behavior are the most accurate. This argument is subject to two significant criticisms. First, the value of

12x Cf. Cross v. Harris, 418 F.2d 1095, 1100-03 (D.C. Cir. 1969) (suggesting a similar balancing formula for commitments under an act governing sexual psychopaths).

t2 349 F. Supp. 1078 (E.D. Wis. 1972), vacated and remanded for a more specific order, 414 U.S. 473 (1974), order on remand, 379 F. Supp. 1376 (1974), vacated and remanded on other grounds, 421 U.S. 957 (1975), order reinstated on remand, 413 F. Supp. 1318 (1976).

130 Id, at 1091.

I3I Id. 
overt dangerous behavior in predicting danger to self rests only on the reasonable expectation that people will behave as they have in the past because no study has examined whether reliance on overt behavior would increase predictive accuracy in this context. ${ }^{132}$ Nor is it clear that more correct prediction is needed for some categories of dangerousness; for example, the danger of suicide or self-injury can be predicted with significantly greater reliability than danger to others. ${ }^{133}$ Second, the proper balancing of the competing interests does not necessarily result in the balance effected by an overt dangerous behavior requirement. The proper balance might require a greater likelihood of danger than current predictive skills can achieve, even when based on overt dangerous behavior. ${ }^{134}$ On the other hand, the balance might require no greater likelihood of danger than prediction not based on overt dangerous behavior can achieve, so the states could be left free to allow dangerousness to be shown in a less accurate way.

\section{Conclusion}

The overt dangerous behavior requirement is one response to the difficult problem of reconciling the liberty of the individual and society's interest in controlling persons who are thought to present a danger to themselves or others. Overt dangerous behavior offers an appealing threshold condition for state interference with the liberty of persons who suffer from mental disabilities. It avoids the controversies that surround the need for treatment as a ground for commitment and reinforces the sadly inaccurate psychiatric predictions of dangerousness with a common sense support. Moreover, commitments made on the ground of overt dangerous behavior resemble criminal convictions closely enough to relieve some of the tension between the retribution-deterrence approach and the prediction-prevention approach. Given these attractions, the interest of both legislatures and courts in the overt dangerous behavior requirement is not surprising.

An option that is an attractive choice for a legislature, however, may be less appealing as a constitutional mandate. Some lower courts have been willing to deal in the abstract, building constitutional doctrine out of such general concepts as dangerousness, treat-

132 See text at notes 92-105 supra.

133 See text and notes at notes 101-102 supra.

Is For example, the best predictions of dangerousness to others based on overt dangerous behavior still identify two false positives for every true positive. See text and note at notes 91-92 supra. 
ment, and overt dangerous behavior. The rationales advanced by these courts suggest that an overt dangerous behavior requirement may be one way to meet some constitutional objections to present standards for involuntary civil commitment but will not support the broader propositions that such a requirement is always necessary or sufficient to satisfy the Constitution.

The Supreme Court has followed a more cautious course. In an area where generalizations mask extremely complex and difficult issues, the Court has chosen a method of analysis-due process interest balancing-that is inherently flexible and dynamic. ${ }^{135}$ The Court has refused to judge the sufficiency or necessity of the generally advanced rationales for involuntary civil commitment. Instead the Court has focused on the particular facts of extreme cases where due process was conspicuously lacking, leaving the legislatures free to experiment with and to develop various alternatives where the balance of interests is closer and more controversial.

Reed Groethe

115 See O'Connor v. Donaldson, 422 U.S. 563 (1975); Jackson v. Indiana, 406 U.S. 715, 731-39 (1972). The Court has even more frequently employed an equal protection analysis in cases involving challenges to the standards used for commitment. See note 20 supra. Equal protection analysis allows the Court to limit its decision to a consideration of the proper application of a state legislature's prior determination of what the standard for commitment should be. 